\title{
The Decisive Moment as an Event in Photographic Discourse
}

\author{
Leny Pimenta \\ Monteiro Lobato-COC High School, Franca, Brazil
}

\author{
Dionéia M. Monte-Serrat \\ University of São Paulo, Ribeirão Preto, Brazil
}

\begin{abstract}
We propose using the concept of decisive moment in order to deconstruct the obvious ideological effects found in discourse. The subject is constituted in enunciation, and its polysemic discourse clashes with the transparency of meaning. According to Pêcheux (1988), the contradictions in discourse simultaneously establish regularity and instability of meanings, leading it to misunderstanding, to the event. Photography destabilizes that which is already formulated and brings out that which is new, the unexpected meaning, the decisive moment. We analyze this process in the picture by Sebastião Salgado- "The cradle of inequality lies in the inequality of the cradle".
\end{abstract} (CAPES-BEX 4394/10-0, FAPESP 09/54417-4, CNPq.)

Keywords: discourse, ideology, subject, event, decisive moment

(...) A expressão reta não sonha. Não use o traço acostumado.

A força de um artista vem de suas derrotas. Só a alma atormentada pode trazer para a voz um formato de pássaro.

Arte não tem pensa: O olho vê, a lembrança revê, e a imaginação transvê.

É preciso transver o mundo. (...)

- Manoel de Barros

Livro sobre nada (2006)

\section{Introduction}

When we associated the concept of "decisive moment" in photography with the discourse analysis of a photograph by Sebastião Salgado (Salgado \& Buarque, 2006) entitled "The cradle of inequality lies in the inequality of the cradle", we intended to attempt to write about what "the art of reflecting in intervals would be" (Pêcheux apud Orlandi, 2006, p. 7), as it establishes new reading gestures from a procedure that deconstructs the "logically stabilized universe" (ditto, p. 8). The appearances, the evidence, and the obvious are questioned in order to deconstruct the naturalized look which, according to Pêcheux (1988), results from an ideological effect.

The expression "decisive moment" embraces the notion of escape points, which are points where meaning "slips", since when we choose a certain meaning, we feel as if we are chosen, displaced to unusual sites and other

Leny Pimenta, Principal at Monteiro Lobato-COC High School, Franca, SP, Brazil. Member of the AD-Interfaces Research Group, registered at CNPq and coordinated by Dr. Leda Verdiani Tfouni, FFCLRP-USP. E-mail: leny@cocfranca.com.br.

Dionéia M. Monte-Serrat, Collaborating Researcher at IEL-UNICAMP, Ph.D. in Psychology from the College of Philosophy, Sciences and Letters of the University of São Paulo, FFCLRP-USP, Ribeirão Preto, SP, Brazil. Split-site doctoral studies conducted at Sorbonne Nouvelle, Paris, under co-supervision by Professor Jean-Jacques Courtine, Sep./Dec. 2010, CAPES-BEX 4394/10-0; doctoral training at École des Hautes Études en Sciences Sociales, EHESS, Paris, under supervision by Professor Marcello Carastro, Feb. 2012, FAPESP 09/54417-4. Faculty member at Ribeirão Preto University. E-mail: di_motta61@yahoo.com.br. 
meanings that are different from those proposed by the photographic image, which captures something else. If photography is not only the static reproduction of reality, then it can be understood as an esthetic experience, as an art that establishes a connection between image and desires, interpretations, sensations, memory. Photography is made into discourse by a subject that appreciates it; and through it we can see through the world. "Seeing through" means "going beyond" in the words by Manoel de Barros (2006); it means being entangled in the web of other discourses and other voices, making memory recognize that it is crossed by words already spoken, updated by historicity (Barros, 2006). In order to articulate these concepts of memory, discourse, photography, and displacement of meanings, we turn to the French philosopher Michel Pêcheux and to his Discourse Analysis Theory.

\section{Memory and Subject in Discursive Formations}

The concept of discourse by Pêcheux (1988) does not lie on the surface of a phrase. In order to define it, the author takes into account effects of meaning between interlocutors placed in a social and historical setting. He (Pêcheux, 1988) takes the concept of discursive formation (DF), developed by Foucault $(1969,1997)$, in order to relate the production of statements that follow the same formation rules and that lead to the same ideological formation (IF). Thus understood, the discursive formation (DF) determines what can and must be said from a historically determined social place. Within this reasoning, we can understand that words, when uttered, acquire a meaning because they relate to ideological positions that already exist in the socio-historical process. Finally, words relate to an ideological exterior marked by ideological formations (Gregolin, 2011).

At one point, Michel Pêcheux (apud Gregolin, 2011) reformulates the concept of discursive formation (DF) in his materialist theory of discourse in order to highlight the fact that discursive processes develop on a linguistic basis and, at the same time, are part of an ideological relationship based on contradiction. To Pêcheux, such contradiction in discourse cannot be easily perceived due to the fact that in the discursive formation (DF), that is, within that which establishes what can and what cannot be said, there is concealment. This effect, according to Pêcheux (1988), occurs by means of the transparency of meaning, of ideology. The author explains that the Ideological State Apparatuses, ISAs (Althusser, 1999) shelter the ideological instance and produce-reproduce society, the State and "free and equal" subjects as "natural evidence". Such contradictory base of the ideological relation disguised by the transparency of meaning causes the instability and heterogeneity of discursive formations (DFs) to become difficult to perceive by discourse analysts (Gregolin, 2011), as something "always says before, outside or independently" and influences the constitution of the subject and of meanings in the discursive process (Pêcheux, 1988, p. 147).

Courtine (apud Gregolin, 2011) proposes thinking of discursive formations as if they were moving borders, as something whose movement is driven by discursive memory. Thus, one can account for the fact that every discourse formation (DF) has relationships with other formulations that it repeats, rejects, transforms, and denies so as to cause certain specific memory effects to be produced. To Gregolin (op. cit.), the notion of discursive formation is articulated to the notion of memory, whose work leads to the production of a memory or oblivion; it leads to the reiteration or silencing of statements. According to the author (op. cit.), the concept of discursive formation integrates the notions that Foucault $(1969,1997)$ elaborates on events, discursive practices and filing, so as to strengthen the dialectical relationship between singularity and repetition, regularity and dispersion. This 
dialectical relationship articulates something that has been stated to the past and also to the future of the story (which acts in the constitution of such statement and determines it).

The fact that memory leads to tension between the boundaries of discursive formations produces instability in meanings and brings, according to Gregolin (op. cit.), the idea developed by Pêcheux (1990) that "every discourse is a potential index of a stir in socio-historical affiliations" (pp. 56-57), an "action of shifting" discursive formations within memory networks and the social courses of meanings. It is in this tension that Pêcheux (1990, apud Gregolin, 2011) identifies the existence of a reorganization of the statement, which moves discursively from one meaning and drifts to another. In this case, the socio-historical context and that of discourse circulation means are considered as something that cannot be dissociated from the statements; they are support material that sustains discourses (as has been said before).

With this quick explanation on the discourse theory, it is not difficult to understand that, alongside the discourses determined by discursive formations (DFs), Pêcheux $(1982,1997)$ contemplated the existence of a "memory under the history that grooves the unwritten file of "underground' discourses"; the existence of conflicts that hiddenly lead to "underground, different and/or contradictory cleavages for reading a file" (p. 57). This contradictory process in which discourse is constituted leads us to give importance to and observe fragments of enunciation that might otherwise go unnoticed. It is in this dialectic involving the regularities and instability of meanings in verbal or non-verbal discourse that we included photography in order to relate the concept of decisive moment — as the concurrency of an event and the expression of forms addressed by Bresson (2011) — to the concept of discursive event developed by Pêcheux (2006).

\section{Event}

When observing statements that refer to similar facts but do not construct the same meanings, Pêcheux (2006, p. 9) wonders about the reason why, in a "semantically normal" world, the "misconception region where the unconscious and ideology are materially connected" is not taken into account. In this inquiry, he proposes the notion of event, which is overdetermined by a metaphorical game around the statement and makes the equivocality of meaning of such statement stand out (op. cit., p. 22). When the author (op. cit.) proposes the comparison between "logically stabilized discursive spaces" and "that which is real", he says that, in the latter, there are "points of the impossible" where "there is independence of the object in face of any discourse concerning it" (op. cit., p. 29).

To Pêcheux (2006, p. 51), there is something structural in the discursive materiality that is symbolic and makes meaning change, escape from any rules established a priori and be taken "in the indefinite relaunch of interpretations", featuring a "swinging and paradoxical character" (op. cit., p. 52). When the subject interprets, he does not do so in an unregulated fashion because, in this case, "memory networks" give way to "identifying affiliations" (Pêcheux, 2006, pp. 54-55) which put "the other-discourse as a virtual space for reading such statement" where the latter is marked by the social space and by historical memory.

Then, it can be said that a particular object, a photograph, for example, can claim interpretation, pose questions and place the discourse of a moving subject in history and in language. Signification is next to the subject who sees, re-reads, sees through, and interprets it; and not next to the object. And if we find and construct meanings, there is always something that escapes us, points of the impossible that we refer to, from the 
perspective of psychoanalysis and Discourse Analysis, as real (Lacan, 1998a; Pêcheux, 2006).

Photography comprehends the effects of what is real for, in the choice of capturing an image and in the obscure elements of that choice, we are faced with something we do not know what it is. An example of it is that of the captured photographer who, when willing to seek something with his objective lens, concludes: “(...) therefore, finally, here is the definition of image, of all images: an image is that from which I am excluded" (Barthes, 2007, p. 211). The look is offset by the order of the desire of the object to be captured, and the photographer is at the mercy of this effect.

Photography, as an art that requires the use of sensitivity, leads to re-encountering the place of origin of a "déjà vu", which is familiar. It can be seen as the place where structure and the event of discourse encounter, as described by Pêcheux (2006, pp. 19, 23): "The event (...), in its current context and in the memory space that it convenes and already begins to reorganize", triggers the action of what comes from the structure, so it is subject to several significations; it is polysemic, heterogeneous, polyphonic, and "has a variable logical stability".

\section{Decisive Moment}

When we address the relationship between image and reality, we are also talking about a subject that provides support to such relationship. Subjectivity is fundamental for us to articulate the Discourse Analysis theory (Pêcheux, 1988) to what Bergson (1990) refers to as memory dynamism (memory-habit) and to the concept of decisive moment as a discursive event, a fleeting moment when drifting seems to stop. The subject, as support, is affected in his stability and, at the same time, by what is unusual. If photography were understood only as a message without a code (Barthes, 2007), such as in systems where only shades, lines, and surfaces are valued, the subject would not matter in this process, but it can cause the emergence of feelings and emotions even if the subject-support is unaware of it.

The concept of decisive moment is related to the concept of time. According to Lacan (1998a, pp. 197-228), time, defined as logical time, includes the instant of seeing, time to understand, and time to conclude. In logical time, a "transformation", an anticipatory assertion, according to Lacan (op. cit.), will reveal the ambivalent subject who, being surpassed, surpasses alienation and inscribes his singularity in the universal field. Would it, then, be possible for a photograph to eternize an image, even if it is a fabricated "truth"?

Photography embraces this paradox, since, at the same time a captured image grasps reality, and it also reflects its author's views and reveals discursive marks. Cartier-Bresson (2011), before the picture by Martin Munkasci-where three black naked boys, seen from the back, run toward ocean waves in a dance choreography_was confused by the movement, by the free forms virtually frozen in the photograph. 


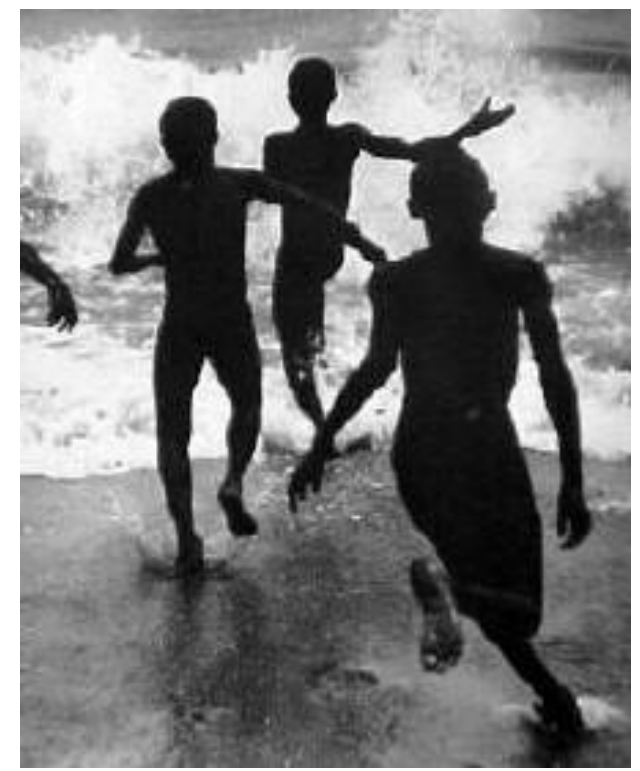

Figure 1. Munkacsi (1929, 2012).

Bresson was impressed by this photograph and began to conceive photography as "a simultaneous recognition, in a fraction of a second, of the meaning of the event as well as of an accurate organization of the forms which give the event its exact expression". This process caused by photography is referred to as the decisive moment and leads us to understand the social reality beyond what is observed every day and beyond social rites.

\section{The Decisive Moment as a Discursive Event in Photography}

Pecheutian Discourse Analysis (DA) is a broad field of studies where the concepts necessary to analyze events in the discursive chain can be found, for, as previously stated, discourse consists of effects of meaning between interlocutors who are set in history and use the materiality of language. Our attempt to establish a dialogue between DA and photography aims at understanding how the subject is constituted within a historically determined social practice without realizing that such practice directs his look and that, despite such "control", discourses with unexpected meanings emerge.

By taking photography as a discursive practice, as a historical process and a product of language (according to DA), in order to interpret meanings, we used articulations that enunciation establish with history and with memory. We understand that memory is not only a set of experiences occurring at different times and spaces from those at the present moment, but it is the discursive memory that constitutes meanings and binds the subject's discourse to the ideology that interpellates him. According to Pecheutian Discourse Analysis theory (Orlandi, 2007, p. 10), there is a "dual memory game: that of the institutional memory, which stabilizes, crystallizes and, at the same time, that of the memory constituted by oblivion, which is what makes difference, rupture and the other possible" (Orlandi, 2007, p. 10). Memory, as inter-discourse and as a condition for discourse production, causes

\footnotetext{
${ }^{1}$ Une photographie est pour moi la reconnaissance simultanée, dans une fraction dês seconde, d'une part de la signification d'um fait, et de l'autre, d'une organisation rigoureuse des formes perçues visuellement qui expriment ce fait (Bresson apud Tériade, 1952/2011, s. p.).
} 
its other production conditions (context, protagonists, and object) to work, bringing effects on understanding and interpretation. Since we aimed at interpreting a photograph, although there is the "meaning-there" of memory, we can perceive discontinuity, ruptures, in the interpreted meaning. This is due to the fact that photography, as a file, relates the institutional, cultural, political, and economic practices of a subject that is subjected to the ideology and practices of the memory constituted by oblivion. We will seek to "denaturalize" the meanings placed by the ideology of institutional practices and attempt to expose the discursive processes in which the "evidence" of meaning emerges; we will seek to reflect on photography as described by Manoel de Barros (2006): We will "see through" a photograph; we will observe what is beyond the obvious aspects that it intends to convey.

\section{Analysis of a Photograph}

Sebastião Salgado (Salgado \& Buarque, 2006) is the selected photographer. His photograph entitled "The cradle of inequality lies in the inequality of the cradle" was taken in the cocoa region, Bahia, in 1990.

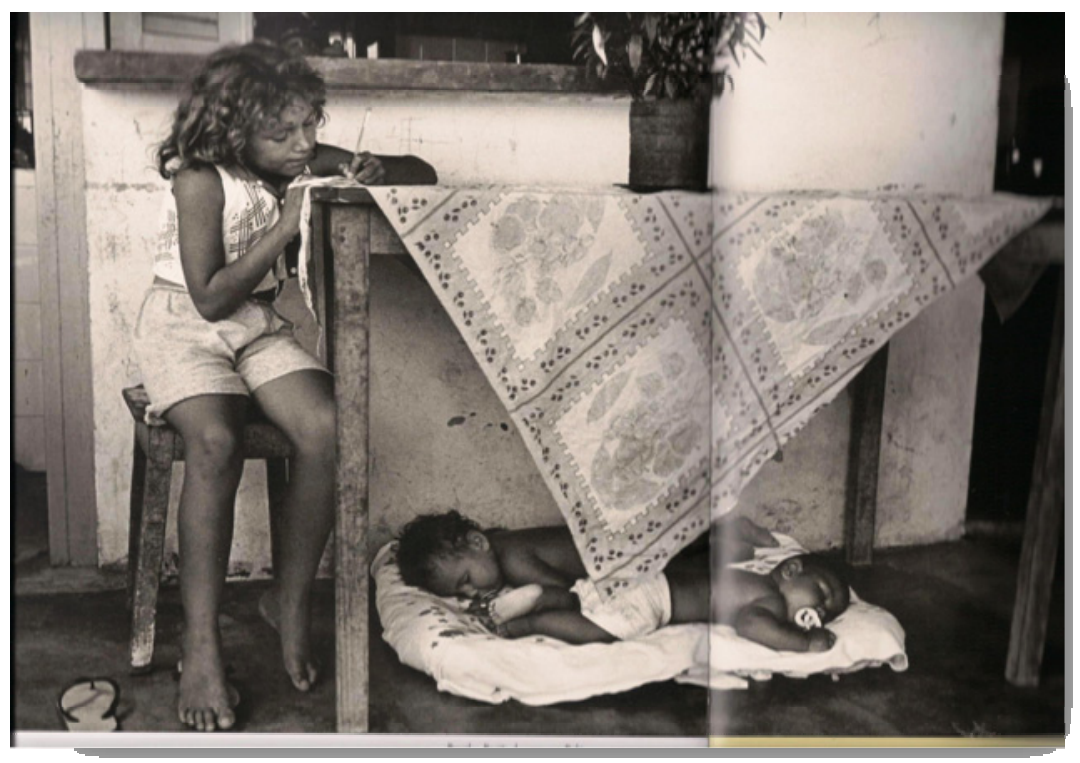

Figure 2. The cradle of inequality lies in the inequality of the cradle (Salgado \& Buarque, 2006, pp. 92-93).

The approximation between the enunciation "The cradle of inequality lies in the inequality of the cradle" and the image in the photograph requires from the observer elaborate thought that associates the idea of the text with what can be seen. Such a process leads the observer to attribute meaning to the gap between the photograph and the enunciation, thus breaking the interpretative linearity of the meaning that would supposedly be transparent; it requires possible analogies that can establish a relationship between "cradle" and "inequality".

The possibility of other interpretations caused by the text that entitles the photograph can be explained by the psychoanalytical perspective of Discourse Analysis (Pêcheux, 1988), which takes into account the effect dimension of the signifier proposed by (1998a, p. 196), thus leading us to conclude that:

Subjectivity is a site that plays a dual function: that of showing subjection and that of showing its subversion. The manifestation of the unconscious provides the opportunity for something new to arise; the unconscious 
"makes the rupture between concepts and the language that enacts them play incessantly" (Leite, 2005, p. 79); it "continually produces a formidable disjunction (...) between language and the conceptualization process" (Rey, 1981, p. 159). Such dual function of subjectivity appointed by psychoanalysis delineates the symbolic economy, so that, from time to time, we may be able "to break the vicious circle that generates the 'totalitarian' closure" (Zizek, 1996, p. 34; Monte-Serrat, 2011).

As learned from Lacan (1957, 1998b, p. 501) "no signification can be sustained except on the remission of another signification". The movement to search for a file consisting of sayings under sayings leads to constant tension between deleting and electing meanings, perpetuating some and silencing others.

Taking historical contradiction into account is taking the file as a discursive site of tension. If there is a file, that is because there is, at the same time and in a contradictory fashion, the rise and the deletion of the "memory of events", the latter being represented by an insertion of materiality in certain historical and social conditions, leading to the production of the event as an effect of a material dispersion (Foucault, 1971, 2003, pp. 53-58).

We can observe the dialogue established between the two ideas in the sentence "The cradle of inequality lies in the inequality of the cradle" and find it strange that the enunciation "cradle of inequality" is inverted to "inequality of the cradle", thus assuming a slippage of meaning and making different voices emerge. The first time the word "cradle" appears, there is an enunciating subject speaking of a universal site in which the meaning of "birthplace", "country" is attributed to "cradle". The second time "cradle" is mentioned, there is a new signification based on the subject's position as part of collectivity, bringing the meaning of "home". Such collective site, from where the subject enunciates, is situated in the discursive formation of cultural identity, thus individualizing each "cradle". In this case, there is the enunciative event, a relation of belonging to a "home", to a "culture", to a "social class" that identifies nameless subjects on black and white photographs.

The dialogue of Pêcheux's theory (1982, 1997, p. 57) — to whom a file is the socio-historical discursive field of relevant and available documents on a certain issue - with the psychoanalysis theory, which takes the unconscious into account, allows us to think about the discursive movement of silencing and of saying, of filing, and of letting sayings slip through the cracks of oblivion.

We can conceive photography as something that enables the event, the emergence of new meaning that outcrops from meanings that have previously been worked on by the ideology of transparency and of the obvious. The "black and white" image denounces the paradox of the event in the larger enunciative space - "country" - and in the individualized space - "home". The color "black" leads to the discursive memory of inferiorization, of class struggle, and of social inequality; whereas the color "white" leads to the discursive memory of hierarchization. The "white" becomes a "background" that highlights the color black, showing social inequality, and denouncing the dominant and settled meaning, which brings prestige and legitimacy with it, thus crystallizing the game of power (Orlandi, 1996).

\section{Conclusion}

The concept of photography changes when we can conceive that it is something that enables the event and deconstruct the obvious ideological effects found in discourse. The subject is constituted in enunciation, and its polysemic discourse clashes with the transparency of meaning. Photography is a tool for destabilizes that which is already formulated; photography can bring out that which is new, the unexpected meaning, the decisive moment. 


\section{References}

Althusser, L. (1999). Ideologia e Aparelhos Ideológicos do Estado (Idelogy and ideological state apparatuses). In S. Zizek (Org.), Um mapa da ideologia (Mapping ideology) (pp. 105-142). Rio de Janeiro: Contraponto.

Barros, M. de. (2006). Livro sobre nada (Book about nothing) (12a ed.). Rio de Janeiro: Record.

Barthes, R. (2007). Fragmentos de um discurso amoroso (Fragments d'un discours amoureux). (M. V. M. de Aguiar, Trans.). São Paulo: Editora Martins Fontes.

Bresson, C. H. (2011). Graphos Facon UFJF 2011. Retrieved from http://fotojornalismojf.wordpress.com/especial/aulas/henri-cartier-bresson/

Foucault, M. (1969/1997). A arqueologia do saber (Archaeology of knowledge). Rio de Janeiro: Forense Universitária.

Foucault, M. (1971/2003). A ordem do Discurso (Orders of discourse) (9a ed.). (L. F. D A. Sampaio, Trans.). São Paulo: Loyola.

Gregolin, M. (2011). Formação discursiva, redes de memória e trajetos sociais de sentido: mídia e produção de identidades (Discursive formation, memory and social paths of meaning: Media and production of identities). Retrieved April 11, 2011 from http://www.uems.br/na/discursividade/Arquivos/edicao02/pdf/Maria\%20do\%20Rosario\%20Gregolin.pdf

Lacan, J. (1998a). Escritos (Writings). (de V. Ribeiro, Trans.). Rio de Janeiro: Jorge Zahar.

Lacan, J. (1957/1998b). A instância da letra no inconsciente ou a razão desde Freud (Instance of the letter). In de V. Ribeiro (Trans.), Escritos (Writings). Rio de Janeiro: Jorge Zahar.

Leite, V. (2005). Só há Causa daquilo que Falha (There is only cause for what fails). In Estudos da Lingua(gem) (Language studies), Vitória da Conquista, n. 1, pp. 77-82.

Monte-Serrat, D. (2011). A tragicidade do sujeito do discurso (The tragicness of the discourse subject). Presented at The Round Table "O trágico nas Ciências Humanas", during The II Jornada AD-Interfaces "Os discursos sobre o trágico na contemporaneidade", FFCLRP-USP.

Munkacsi, M. (2010). Black boys ashore Lake Tanganyika, Hungary. Retrieved from http://www.google.com.br/imgres?imgurl=http://1.bp.blogspot.com/_wzpxvhgwq3c/S0ftp-awcqI/AAAAAAAAKO8/UmY0f Y7aquI/s400/FP-Martin\%2520Munkacsi.jpg\&imgrefurl=http://bloguilheu.blogspot.com/2010/01/martin-munkacsi.html\&usg $=$ FWzT8RHBDi8RZpBbP5UvSjsIsoc $=\& \mathrm{~h}=400 \& \mathrm{w}=277 \& \mathrm{sz}=30 \& \mathrm{hl}=\mathrm{pt}-\mathrm{BR} \& \mathrm{star}=3 \& \mathrm{zoom}=1 \& \mathrm{tbnid}=\mathrm{L} 3 \mathrm{AAV} 76 \mathrm{YtnEmz}$ M:\&tbnh=124\&tbnw=86\&ei=TWnkT9PoJMjD0AGb-pzZCQ\&prev=/search\%3Fq\%3DFoto\%2Bde\%2BMARTIN\%2BMU NKACSI.\%2B1929.\%26hl\%3Dpt-BR\%26gbv\%3D2\%26tbm\%3Disch\&itbs=1

Orlandi, E. (1996). Interpretação: autoria, leitura e efeitos do trabalho simbólico (Interpretation: Authoring, reading and effects of symbolic work). Petrópolis: Vozes.

Orlandi, E. (1999/2007). Análise de discurso: princípios e procedimentos (Discourse analysis: Principles and procedures) (7a ed.). Campinas: Pontes.

Orlandi, E. (2006). Linguagem e seu funcionamento: as formas do discurso (Language and its operation: The forms of discourse) (4a ed.). Campinas: Pontes.

Pêcheux, M. (1988). Semântica e discurso: uma crítica à afirmação do óbvio (Les verités de la Palice) (Semantics and discourse: A critique of the statement of the obvious). (E. P. Orlandi, Trans.). Campinas: Editora da Unicamp.

Pêcheux, M. (1990). Remontons de Foucault a Spinoza (Let's go back from Foucault to Spinoza). In The restlessness of the speech (re)read Michel Pêcheux today. Paris: Ed. Cendres.

Pêcheux, M. (1982/1997). Ler o arquivo hoje (Read the file today). In E. P. Orlandi (Org.), Gestos de Leitura (Read gestures). Campinas: Editora Unicamp.

Pêcheux, M. (2006). Discurso: Estrutura ou Acontecimento? (Discourse: Structure or event?) (5a ed.). (E. P. Orlandi, Trans.). Campinas: Pontes.

Rey, J. M. (1981). L'épreuve de la psychanalyse (The test of psychoanalysis). In B. Conien, et al. (Org.), Materialités Discursives (pp. 155-161). Lille: Presses Universitaires de Lille.

Salgado, S., \& Buarque, C. (2006). O berço da desigualdade (The cradle of inequality). In O berço da desigualdade (The cradle of inequality). UNESCO: Ed. Grupo Santilhana.

Tériade. (1952). Imagens à La Sauvette: couverture: papier découpé par Matisse (La Sauvette Imagens: Cover paper by Matisse). Verve Paris. Obtained by e-mail from Jessica Retailleau (jessica.retailleau@henricartierbresson.org), from Fondation Henri Cartier-Bresson (www.henricartierbresson.org), 2 impasse Lebouis, 75014, Paris, on August 24, 2011.

Zizek, S. (1996). O espectro da ideología (The spectre of ideology). In T. Adorno (Trans.), Um mapa da ideología (Mapping ideology). Vera Ribeiro, Rio de Janeiro: Contraponto. 